\title{
Riba versus Sedekah
}

\author{
Trisno Wardy Putra \\ Dosen LB Jurusan Syari’ah Prodi Ekonomi Islam \\ Sekolah Tinggi Agam Islam Negeri Sorong \\ trisno-putra@yahoo.com
}

\begin{abstract}
The focus of this discussion concerns the Usury Versus Alms. The purpose of this study is to provide an explanation of how the sharia views towards usury and alms and to find out how the effects of usury and alms. This research is in the form of a comparison between usury and alms in the view of the Qur'an and the Sunnah and through the opinions of the scholars and interpreters of usury and alms. The results of the discussion stated that usury is an activity that is forbidden in the Sharia and will not add to the side of Allah SWT. Furthermore alms is a religious activity that Allah SWT commands to Muslims and of course people who do alms will be receive multiple reward. The impact of usury will have a negative effect comparing to giving charity that gives a positive effect both in personal, economic and social aspects of the community.
\end{abstract}

Keywords: Usury, Alms and Impact

\section{Pendahuluan}

Islam adalah agama yang sempurna, telah diakui dan dijamin Allah Azza Wa Jalla. Hal ini seperti yang dijelaskan Allah Allah Azza Wa Jalla dalam kitab-Nya yang mulia: 


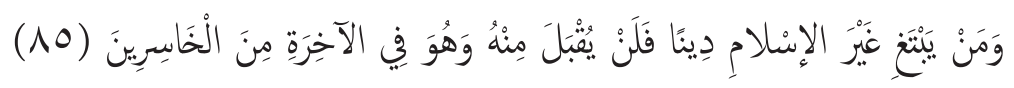

Artinya:

Barangsiapa mencari agama selain agama islam, Maka sekali-kali tidaklah akan diterima (agama itu) daripadanya, dan dia di akhirat termasuk orang-orang yang merugi. (QS. Ali Imran 85).

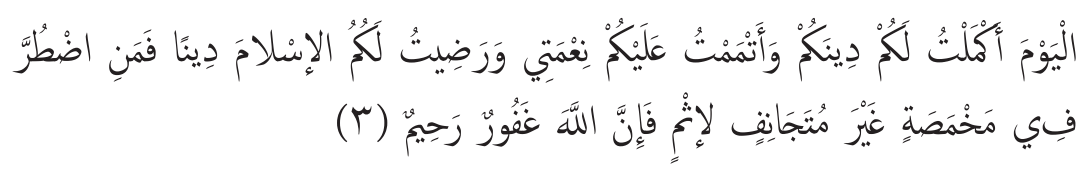

Artinya:

Pada hari Ini Telah Kusempurnakan untuk kalian agama kalian, dan Telah Ku-cukupkan atas kalian nikmat-Ku, dan Telah Kuridhai Islam itu jadi agama bagi kalian. (QS. Al Maidah 3)

Ini berarti bahwa segala aturan dan hukum yang digariskan Islam telah dijamin sempurna. Islam mampu menjamin tercapainya kemakmuran hidup manusia dalam segala bidang, termasuk kesejahteraan ekonomi. Perekonomian merupakan tulang punggung kehidupan masyarakat. Dan Islam sangat melarang segala sesuatu yang dapat merusak kehidupan perekonomian bangsa, seperti riba, gharar dan maysir. Islam juga melarang umatnya menumpuk uang atau menumpuk kekayaan, karena islam tidak membenarkan penganutnya memperkaya dan mementingkan diri sendiri demi keuntungan pribadi, memperbudak, dan memeras si miskin karena perbuatan tersebut akan membuat orang bakhil.

Islam mendorong pemerataan pendapatan dan kemakmuran ekonomi dalam masyarakat. Dan diantara solusi Islam dalam upaya pemerataan pendapatan dan kemakmuran ekonomi masyarakat adalah dengan sedekah.

Salah satu pokok permasalahan yang paling mendasar dari permasalahan ekonomi adalah bukan karena kelangkaan sumber daya alam melainkan karena keserakahan umat manusia itu sendiri. Ia ingin mendapatkan rezeki yang sebanyak-banyaknya untuk kepentingan diri 
sendiri tanpa menghiraukan halal ataupun haram dari cara memperolehnya. Anggapan bahwa rezeki adalah semata-mata materi, harta, dan benda saja itu tidak lain hanyalah pandangan orang-orang kafir yang hidup bergelimang dalam kejahiliyahan, kekafiran, dan kebiadaban yang secara umum terbingkai oleh paham ekonomi materialisme dan determinisme (M. Umer Chapra, 2000 : h. 22).

Karena itulah kekayaan, kepuasan jasmaniah, dan kesenangan sensasi merupakan satu-satunya nilai terbesar yang dapat dicapai oleh manusia. Materialisme telah menyediakan fondasi bagi kultur komersial yang dari waktu ke waktu semakin kokoh dan telah berhasil melipat gandakan jumlah keinginan manusia, jauh dari kemampuan sumbersumber daya untuk memenuhinya (Ibid, h. 23).

Adanya keserakahan yang terjadi dimasyarakat dan melemahnya kaum muslimin dalam menuntut ilmu syar'i, inilah yang menyebabkan perkara-perkara yang haram seperti riba begitu mudah dilakukan oleh masyarakat sebaliknya perkara yang halal seperti sedekah mereka tidak melakukannya dikarenakan tumbuhnya sikap individualisme dan materialis dalam diri masyarakat. Berdasarkan hal tersebut diatas, tulisan ini mencoba membahas permasalahan terkait masalah :

1. Bagaimana konsep riba dan sedekah menurut syariah ?

2. Bagaimana dampak riba dan sedekah ?

\section{Konsep Riba}

\section{Pengertian Riba}

Riba secara bahasa bermakna; ziyadah (tambahan). Dalam pengertian lain, secara linguistik riba juga berarti tumbuh dan membesar (Zainuddin Ali, 2008 : h. 88). Menurut istilah teknis, riba berarti pengambilan tambahan dari harta pokok atau modal secara batil (Ibid, h. 89). Kata riba juga berarti; bertumbuh menambah atau berlebih. Al-riba atau ar-rima makna asalnya ialah tambah tumbuh dan subur. Adapun pengertian tambah dalam konteks riba adalah tambahan uang atas 
modal yang diperoleh dengan cara yang tidak dibenarkan syara', apakah tambahan itu berjumlah sedikit maupun berjumlah banyak seperti yang disyaratkan dalam Al-Qur'an (Muhammad, 2000 : h. 147).

Riba sering diterjemahkan orang dalam bahasa inggris sebagai "usury" yang artinya "the act of lending money at an exorbitant or illegal rate of interest" sementara para ulama' fikih mendefinisikan riba dengan "kelebihan harta dalam suatu muamalah dengan tidak ada imbalan atau gantinya". Maksud dari pernyataan ini adalah tambahan terhadap modal uang yang timbul akibat transaksi utang piutang yang harus diberikan terutang kepada pemilik uang pada saat utang jatuh tempo (Ibid., h. 89). Pada intinya riba adalah tambahan yang didapatkan dengan cara-cara yang tidak dibenarkan dalam syariah dan dapat merugikan salah satu pihak.

\section{Riba Menurut Pandangan Ulama}

Adapun dalam pemahaman syariat, maka para ulama berbeda-beda ungkapan dalam mendefinisikannya, akan tetapi maksud dan maknanya tidak jauh berbeda. Diantara definisi adalah sebagai berikut:

a. Asy-Syarbini dalam kitab Mughni Muhtaj, Riba adalah salah satu akad atau transaksi atas barang tertentu yang ketika akad berlangsung, tidak diketahui kesamaannya menurut ukuran syariat atau dengan menunda penyerahan kedua barang yang menjadi obyek akad atau salah satunya.

b. Ibnu Qudamah dalam Al-Mughni, Riba adalah penambahan komoditi atau barang dagangan tertentu (Muhammad Arifin Bin Badri, 2012, h. 2).

Dari beberapa pengertian yang dirumuskan oleh para ulama tersebut, secara umum terdapat benang merah yang menegaskan bahwa riba adalah pengambilan tambahan yang tidak dilandasi oleh prinsipprinsip syariah dari suatu komoditi atau barang. 


\section{Jenis-Jenis Riba}

Secara umum riba dapat dikelompokkan menjadi dua, yaitu riba utang dan riba jual beli. Riba utang terbagi menjadi dua, yaitu ribâ qard dan ribâ jâhiliyyah. Sementara riba jual beli terbagi juga menjadi dua, ribâ fadhl dan ribâ nasî' 'ah (Muhammad Syafi'i Antonio, 2005, h. 41).

a. Riba Qard ( ربا القرض ) adalah suatu manfaat atau tingkat kelebihan tertentu yang disyaratkan terhadap yang berutang.

b. Riba Jâhiliyyah (ربا الجاهلية) adalah utang dibayar lebih dari pokoknya karena si peminjam tidak mampu membayar utangnya pada waktu yang ditetapkan.

c. Riba fadhl (ربا الفضل ) adalah pertukaran antar barang sejenis dengan kadar atau takaran berbeda, sedangkan barang yang dipertukarkan itu termasuk dalam jenis barang ribawi.

d. Riba nasî'ah ( ربا النسيئة) adalah penangguhan penyerahan atau penerimaan jenis barang ribawi yang dipertukarkan dengan jenis barang ribawi lainnya. Riba dalam nasî'ah muncul karena adanya perbedaan, perubahan, atau tambahan antara yang diserahkan saat ini dan yang diserahkan kemudian.

\section{Hukum Riba}

Tidak seorang muslimpun yang menyangkal haramnya hukum riba. Teks Al-Qur'an begitu jelas menyatakan bahwa Allah telah mengharamkan riba (Erwandi Tarmizi, 2013, h. 331). Allah Ta’ala berfirman,

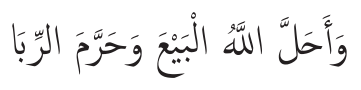

Artinya:

Padahal Allah telah menghalalkan jual beli dan mengharamkan riba. (Al-Baqarah: 275)

Kemudian Allah juga memerintahkan orang-orang beriman untuk menghentikan praktik riba. Allah berfirman: 


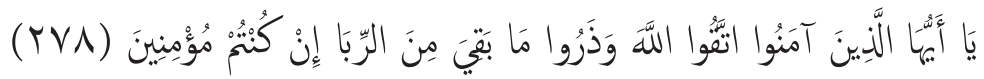

Artinya:

Hai orang-orang yang beriman, bertakwalah kepada Allah dan tinggalkan sisa Riba (yang belum dipungut) jika kamu orang-orang yang beriman. (Al-Baqarah:278)

Dan Allah mengancam akan memerangi orang-orang yang tidak menuruti perintahnya untuk meninggalkan riba. Allah berfirman,

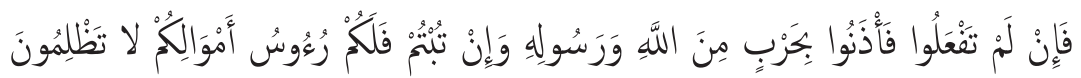
وَلا تُطْلَمُونَ (YV9)

Artinya:

Maka jika kamu tidak mengerjakan (meninggalkan sisa riba), maka ketahuilah, bahwa Allah dan Rasul-Nya akan memerangimu. (Al-Baqarah:279)

Rasulullah SAW. juga telah melarang mengambil riba, sebagaimana sabdanya:

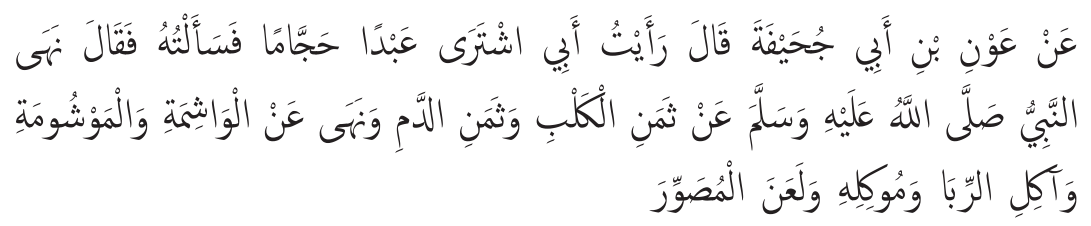

Artinya:

Dari 'Aun bin Abu Juhaifah berkata, aku melihat bapakku membeli seorang budak sebagai tukang bekam lalu aku tanyakan kepadanya maka dia berkata; "Nabi Saw. telah melarang harga (uang hasil jual beli) anjing, darah dan melarang orang yang membuat tato dan yang minta ditato dan pemakan riba' dan yang memberi riba serta melaknat pembuat patung".(HR. Bukhari no. 1944)

Kata (وَحَرَّمَ الرِّبا) dalam Qs. al-Baqarah: 275, maksudnya adalah Allah mengharamkan 'jenis' riba, karena alif dan lam (ال) di sini menunjukkan jenis (للجنس ), bukan menunjukkan apa yang sudah dikenal pada masa 
lampau (للمعرود الذهني) yakni hanya riba jahiliyah atau riba nasî’ah. Tetapi yang dimaksud oleh ayat tersebut adalah kemutlakannya, yaitu haramnya seluruh jenis riba (Wahbah Az-Zuhaili, 1998 : h. 93). Tidak ada beda antara riba dalam jumlah banyak ataupun sedikit. Sebagaimana sabda Rasulullah Saw:

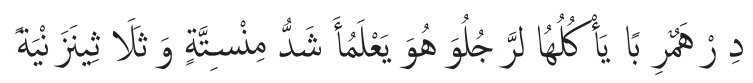

Artinya:

Satu dirham uang riba yang dimakan oleh seseorang dalam keadaan ia tahu bahwa itu adalah uang riba dosanya lebih besar dari pada berzina sebanyak 36 kali." (HR. Ahmad dari Abdullah bin Hanzhalah dan dishahihkan oleh al-Albani dalam Shahih alJâmi', no. 3375)

Dalam hadits di atas dengan tegas Rasulullah mengatakan bahwa uang riba haram meski sangat sedikit yang beliau ilustrasikan dengan satu dirham. Rasulullah Saw juga memasukkan riba dalam tujuh dosa besar yang membinasakan, sebagaimana sabdanya:

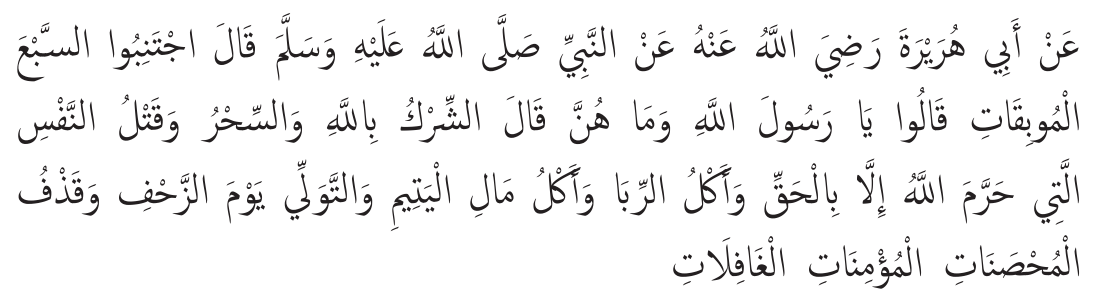

Artinya:

Dari Abu Hurairah r.a. dari Nabi Saw. bersabda: "Jauhilah tujuh perkara yang membinasakan". Para sahabat bertanya: "Wahai Rasulullah, apakah itu? Beliau bersabda: "Syirik kepada Allah, sihir, membunuh jiwa yang diharamkan oleh Allah kecuali dengan haq, memakan riba, makan harta anak yatim, kabur dari medan peperangan dan menuduh seorang wanita mu'min yang suci berbuat zina. (HR. Bukhari no. 2560) 
Allah SWT juga memerintahkan untuk sabar menghadapi orang yang belum mampu membayar hutang. Lalu Allah menetapkan bahwa jika memang orang tersebut fakir, sedang mengalami kesulitan ekonomi dan belum mungkin membayar hutangnya pada waktu yang ditetapkan, maka hendaknya diberi tangguh dan tunggu hingga ia mampu.

\section{Konsep Sedekah}

Sedekah (صدقة) berasal dari kata shadaqa (صدق يصدق) yang berarti benar. Orang yang suka sedekah adalah orang yang benar pengakuan imannya. Sedangkan menurut terminologi syariat (istilah), pengertian sedekah sama dengan pengertian infaq, termasuk juga hukum dan ketentuan-ketentuannya. Hanya saja, jika infaq berkaitan dengan materi, sedekah memiliki arti yang luas, menyangkut hal yang bersifat nonmaterial (Didin Hafidhuddin, 2008, h. 15).

Hadist Riwayat Imam Muslim dari Abu Dzar, Rasulullah menyatakan bahwa jika tidak mampu bersedekah dengan harta maka membaca tasbih, membaca takbir, tahmid, tahlil, berhubungan suami istri, dan melakukan kegiatan amar ma’ruf nahi mungkar adalah sedekah. Seringkali kata-kata sedekah di pergunakan dalam Al-Qur'an, tetapi maksud sesungguhnya adalah zakat, misalnya firman Allah dalam surat at-Taubah: 60 dan 103. Yang perlu diperhatikan, jika seseorang telah berzakat tetapi masih memiliki kelebihan harta, sangat dianjurkan sekali untuk berinfaq atau bersedekah.

Menurut definisi di atas, sedekah dapat kita bedakan dalam dua jenis, yaitu sedekah materi dan sedekah non materi (lihat: http//:www. kaliakbar.com, di akses pada tanggal 05 Juni 2015 pukul. 07.31 WIB).

\section{Sedekah Materi}

Sedekah materi di sini dapat berupa beberapa hal, antara lain:

a. Zakat. "Sesungguhnya sedekah-sedekah (zakat-zakat) itu adalah bagi orang-orang fakir, orang-orang miskin, amil-amil zakat ...” (QS. AtTaubah: 60). Sedekah yang dimaksud dalam ayat ini adalah zakat. 
Zakat sendiri adalah sejumlah harta tertentu yang telah mencapai syarat tertentu yang diwajibkan oleh Allah untuk dikeluarkan dan diberikan kepada yang berhak menerimanya dengan persyaratan tertentu pula. Zakat tersebut hukumnya adalah wajib bagi yang telah mencapai haul dan nisab.

b. Menafkahkan Harta di Jalan Allah. Allah Tabaraka wata'ala berfirman (dalam hadits Qudsi): "Hai anak Adam, berinfaklah (nafkahkanlah hartamu di jalan Allah), niscaya Aku memberikan nafkah kepadamu." (HR. Muslim). Melalui hadits qudsi ini, Allah SWT telah memerintahkan umatnya untuk menginfakkan harta yang dimilikinya di jalan Allah SWT. Di sini, harta yang diinfakkan tersebut hukumnya sunnah. Contoh dari menafkahkan harta di jalan Allah antara lain infaq pembangunan musholla, menyantuni anak yatim dan menafkahi istri, sebagaimana sabda Nabi Shalallahu 'alaihi wasallam:

Apa yang kamu nafkahkan dengan tujuan keridhoan Allah akan diberi pahala walaupun hanya sesuap makanan ke mulut isterimu. (HR. Bukhari).

\section{Sedekah Non Materi}

Bentuk sedekah non materi ini sangatlah beragam, antara lain:

a. Bekerja dengan ketrampilan tangan, menolong orang yang sedang teraniaya, amar ma'ruf nahi munkar dan mencegah diri dari berbuat kejahatan.Dalam suatu riwayat dikisahkan:

Tiap muslim wajib bersedekah. Para sahabat bertanya, "Bagaimana kalau dia tidak memiliki sesuatu?" Nabi Saw menjawab, "Bekerja dengan ketrampilan tangannya untuk kemanfaatan bagi dirinya lalu bersedekah." Mereka bertanya lagi. Bagaimana kalau dia tidak mampu?" Nabi menjawab: "Menolong orang yang membutuhkan yang sedang teraniaya" Mereka bertanya: "Bagaimana kalau dia tidak melakukannya?" Nabi menjawab: "Menyuruh berbuat ma'ruf." Mereka bertanya: 
"Bagaimana kalau dia tidak melakukannya?" Nabi SAW menjawab, "Mencegah diri dari berbuat kejahatan itulah sedekah." (HR. Bukhari dan Muslim).

Dalam hadits ini, terlihat bahwa Rasulullah SAW tidak ingin mem-bebani umatnya dengan hal-hal materil, namun Beliau ingin agar umatnya menyedekahkan apa yang memang mampu disedekahkannya walaupun hanya menjauhkan diri dari kejahatan.

b. Memberikan senyum kepada kawan

Nabi Muhammad Shalallahu álahi wasallam bersabda:

"Tiap-tiap amalan makruf (kebajikan) adalah sedekah. Sesungguhnya di antara amalan makruf ialah berjumpa kawan dengan wajah ceria (senyum) dan mengurangi isi embermu untuk diisikan ke mangkuk kawanmu." (HR. Ahmad).

Dalam hadits ini, Allah SWT memberikan kemudahan bagi umatnya dalam bersedekah. Cukup dengan memberikan senyum kepada kawan, maka sudah dapat disebut sedekah dan dapat meraih pahala dari Allah SWT.

\section{Keutamaan Sedekah}

Di antara keutamaan-keutamaan sedekah antara lain: Pertama, Dilipat gandakan pahalanya sebanyak tujuh ratus kali lipat. Allah SWT berfirman: Perumpamaan (nafkah yang dikeluarkan oleh) orang-orang yang menafkahkan hartanya di jalan Allah adalah serupa dengan sebutir benih yang menumbuhkan tujuh bulir, pada tiap-tiap bulir seratus biji. Allah melipat gandakan (ganjaran) (QS. Al-Baqarah: 261). Dalam ayat ini, Allah SWT memberikan ganjaran yang berlipat-lipat kepada orang yang bersedekah. Dan Allah SWT tidak hanya melipat gandakannya satu atau dua kali, melainkan tujuh ratus kali. Di sini terlihat bahwa sedekeh merupakan amalan yang sangat dianjurkan oleh Allah SWT (Ibid). 
Sebagai penghalang bencana, Dari Ali r.a., Rasulullah SAW. bersabda, "Segeralah bersedekah, sesungguhnya musibah tidak dapat melintasi sedekah." Rasulullah SAW bersabda "Bentengilah hartamu dengan zakat, obati orang-orang sakit (dari kalanganmu) dengan bersedekah dan persiapkan doa untuk menghadapi datangnya bencana" (HR. Ath-Thabrani).

Kedua, Amalan yang tidak putus pahalanya walaupun orang yang beramal tersebut sudah meninggal,Nabi Muhammad SAW bersabda:

Apabila anak Adam wafat putuslah amalnya kecuali tiga hal yaitu sodaqoh jariyah, pengajaran dan penyebaran ilmu yang dimanfaatkannya untuk orang lain, dan anak (baik laki-laki maupun perempuan) yang mendoakannya. (HR. Muslim).

Ketiga, Dapat memperpanjang umur, Nabi Muhammad SAW bersabda: Yang dapat menolak takdir ialah doa dan yang dapat memperpanjang umur yakni kebajikan (amal bakti). (HR. Ath-Thahawi). Hal-hal yang berkaitan dengan umur manusia memang merupakan hak mutlak Allah SWT. Namun di sini Rasulullah SAW memberikan suatu petunjuk bahwa di antara salah satu fadhillah sedekah adalah dapat memperpanjang umur. Kata-kata "kebajikan" di sini dapat diartikan sedekah.

\section{Menjaga Harta dan Berupaya Mengembangkannya}

Islam memandang bahwa harta merupakan salah satu dari perhiasan dunia dan juga sarana dari sekian banyak sarana yang bisa mempermudah hidup manusia. Islam tidak mencela suatu harta (dari sisi bendanya) dan tidak meletakkannya setingkat barang-barang mungkar atau haram. Ia sekadar sarana (media) yang jika digunakan dalam kebaikan, maka ia akan menjadi baik. Dan jika digunakan dalam keburukan, maka ia akan menjadi buruk (Muhammad Asyraf Dawwabah, 2009 : h. 145). Allah Ta’ala berifirman:

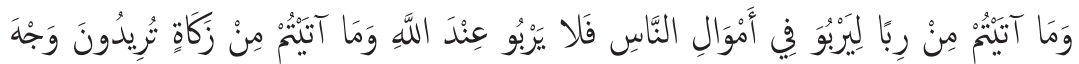

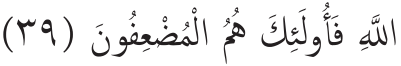


Artinya:

Dan sesuatu Riba (tambahan) yang kamu berikan agar Dia bertambah pada harta manusia, Maka Riba itu tidak menambah pada sisi Allah. dan apa yang kamu berikan berupa zakat yang kamu maksudkan untuk mencapai keridhaan Allah, Maka (yang berbuat demikian) Itulah orang-orang yang melipat gandakan (pahalanya). (QS. Ar-Ruum: 39)

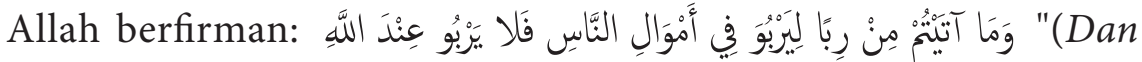
sesuatu Riba (tambahan) yang kamu berikan agar Dia bertambah pada harta manusia, Maka Riba itu tidak menambah pada sisi Allah)." Yaitu, barangsiapa yang memberikan sesuatu guna mengharapkan balasan manusia yang lebih banyak kepadanya dari apa yang diberikan, maka perilaku ini tidak mendapatkan pahala di sisi Allah. Demikian ditafsirkan oleh Ibnu 'Abbas, Mujahid, adh-Dahhak, Qatadah, 'Ikrimah, Muhammad bin Ka'ab, dan asy-Sya'bi. "Sikap seperti ini dibolehkan, sekalipun tidak memiliki pahala. Akan tetapi, Rasulullah Shalallahu 'alaihi wasallam, melarangnya secara khusus.” Itulah yang dikatakan oleh adh-Dahhak dan dia berdalil dengan firman Allah Ta'al: \{ولاتمنن تستكر "Dan janganlah kamu memberi (dengan maksud) memperoleh (balasan yang lebih banyak." (QS. al-Mudatstsir: 6). Yaitu, janganlah engkau memberikan sesuatu karena menghendaki sesuatu yang lebih besar dari pemberianmu itu. Dan Ibnu 'Abbas berkata: "Riba itu ada dua; riba yang tidak sah yaitu riba buyu'/jual beli dan riba yang tidak mengapa, yaitu hadiah yang diberikan seseorang karena berharap kelebihannya dan pelipatannya. Kemudian beliau membaca ayat ini,

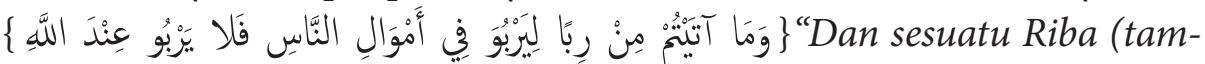
bahan) yang kamu berikan agar Dia bertambah pada harta manusia, Maka Riba itu tidak menambah pada sisi Allah." Sedangkan pahala di sisi Allah ada pada sedekah (zakat) (Abdullah bin Muhammad Alu Syaikh, 2008, h. 226-227).

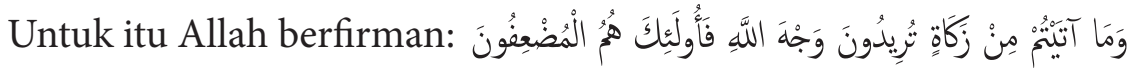
"Dan apa yang kamu berikan berupa zakat yang kamu maksudkan untuk mencapai keridhaan Allah, Maka (yang berbuat demikian) Itulah orang- 
orang yang melipat gandakan (pahalanya)." Yaitu orang-orang yang dilipatgandakan pahala dan ganjarannya (Ibid, h. 227).

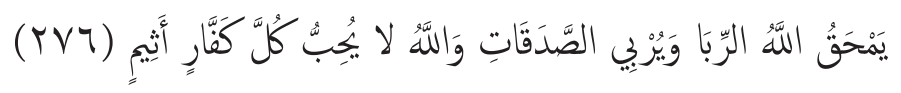

Artinya:

Allah memusnahkan Riba dan menyuburkan sedekah. dan Allah tidak menyukai Setiap orang yang tetap dalam kekafiran, dan selalu berbuat dosa. (QS. Al-Baqarah: 276)

Allah Azza Wa Jalla, memberitahukan bahwa Dia menghapuskan riba, baik menghilangkannya secara keseluruhan dari tangan pelakunya maupun mengharamkan keberkahan hartanya, sehingga ia tidak dapat mengambil manfaat darinya, bahkan dia melenyapkan hasil riba itu di dunia dan memberikan hukuman kelak pada hari kiamat (Abdullah bin Muhammad Alu Syaikh, 2008 : h. 705). Sebagaimana firman Allah Taa'la:

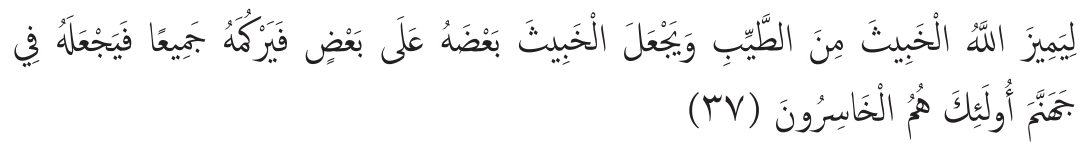

Artinya:

Supaya Allah memisahkan (golongan) yang buruk dari yang baik dan menjadikan (golongan) yang buruk itu sebagiannya di atas sebagian yang lain, lalu kesemuanya ditumpukkan-Nya, dan dimasukkan-Nya ke dalam neraka Jahannam. mereka Itulah orangorang yang merugi.

Imam Ahmad meriwayatkan dari Ibnu Mas'ud, dari Nabi Shalalallahu 'alaihi wasallam, beliau bersabda: "Sesungguhnya riba, meskipun pada awalnya banyak, namun akhirnya akan menjadi sedikit." (HR. Ahmad).

Hadits tersebut juga diriwayatkan oleh Ibnu Majah. Yang demikian itu dari sisi muamalah jelas bertentangan dengan tujuan mengambil riba supaya banyak. Firman Allah Azza wa jalla \{وَيَرِي الرَّدَقَاتِ menyuburkan sedekah." Kata itu dibaca dengan memberikan dhammah

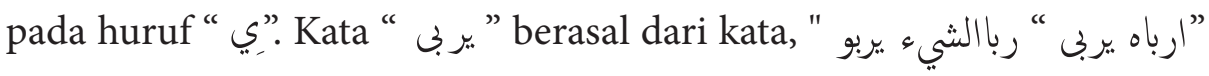


yang berarti memperbanyak dan mengembangbiakkan (Ibid, h. 705).

Imam al-Bukhari meriwayatkan dari Abu Hurairah ra, ia menceritakan, Rasulullah Shalallahu 'alaihi wasallam pernah bersabda:

Artinya:

Barangsiapa bersedekah senilai satu kurma yang dihasilkan dengan usaha yang baik (halal) dan Allah tidak menerima kecuali yang baik, maka sesungguhnya Allah menerimanya dengan tangan kanan-Nya, lalu memeliharanya untuk pelakunya, seperti halnya seseorang di antara kalian memelihara anak kudanya hingga menjadi sebesar bukit." (HR. Al-Bukhari).

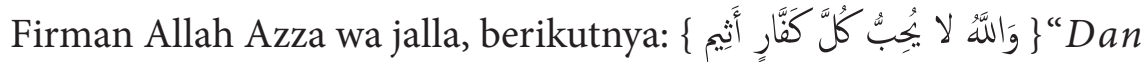
Allah tidak menyukai setiap orang yang tetap dalam kekafiran dan selalu berbuat dosa." Maksudnya, Dia tidak menyukai orang yang hatinya senantiasa ingkar, yang selalu berbuat dosa baik berupa ucapan maupun perbuatan. Penyebutan sifat di atas dalam mengakhiri ayat ini sangatlah tepat. Karena seorang yang melakukan riba itu pada hakekatnya tidak mau menerima yang halal yang ditetapkan Allah baginya dan tidak merasa cukup dengan usaha yang halal tersebut. Bahkan ia berusaha memakan harta orang lain dengan cara yang bathil, yaitu dengan berbagai macam usaha busuk. Dengan demikian, ia telah mengingkari nikmat Allah Tảala yang telah diberikan kepadanya, zalim, dan berbuat dosa dengan memakan harta orang lain dengan cara yang bathil.

\section{Komitmen Dengan Dasar-Dasar Pengembangan Harta}

Agar harta yang dimiliki menjadi sarana ibadah dan kelak berguna di akhirat, maka perlu diperhatikan cara mendapatkannya, yaitu sebagai berikut:

1. Halal (substansi maupun caranya) (Didin Hafidhuddin, 2008 : h. 16).

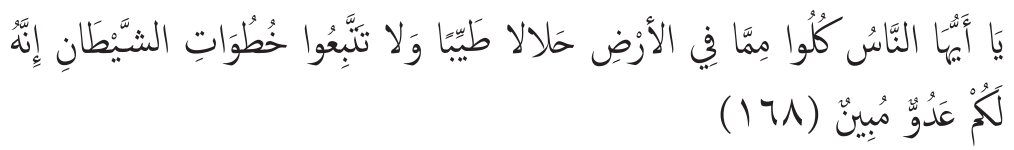


Artinya:

Hai sekalian manusia, makanlah yang halal lagi baik dari apa yang terdapat di bumi, dan janganlah kamu mengikuti langkah-langkah syaitan; karena Sesungguhnya syaitan itu adalah musuh yang nyata bagimu. (Al-Baqarah:168)

2. Tidak Berlaku Zalim

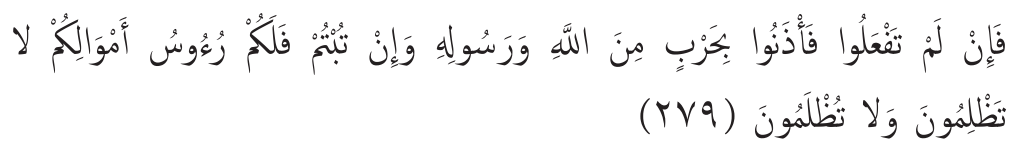

Artinya:

Maka jika kamu tidak mengerjakan (meninggalkan sisa riba), Maka ketahuilah, bahwa Allah dan Rasul-Nya akan memerangimu. dan jika kamu bertaubat (dari pengambilan riba), Maka bagimu pokok hartamu; kamu tidak Menganiaya dan tidak (pula) dianiaya. (Al-Baqarah: 279)

3. Tidak Dengan Cara-Cara Yang Batil

a. Seperti suap-menyuap (risywah)

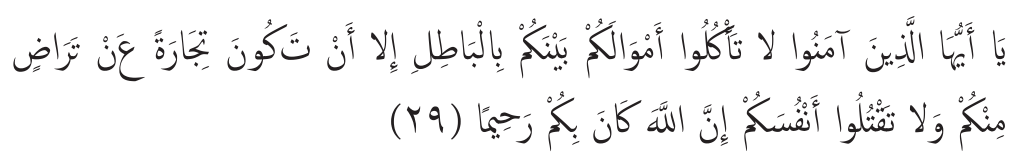

Artinya:

Hai orang-orang yang beriman, janganlah kamu saling memakan harta sesamamu dengan jalan yang batil, kecuali dengan jalan perniagaan yang Berlaku dengan suka samasuka di antara kamu. dan janganlah kamu membunuh dirimu. Sesungguhnya Allah adalah Maha Penyayang kepadamu."(AnNisa: 29).

b. Menipu dan korupsi

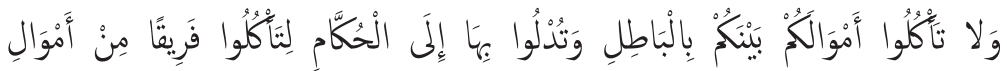

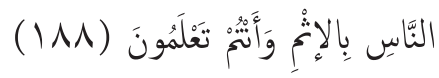


Artinya:

Dan janganlah sebahagian kamu memakan harta sebahagian yang lain di antara kamu dengan jalan yang bathil dan (janganlah) kamu membawa (urusan) harta itu kepada hakim, supaya kamu dapat memakan sebahagian daripada harta benda orang lain itu dengan (jalan berbuat) dosa, Padahal kamu mengetahui. (Al-Baqarah: 188)

c. Berbuat riba

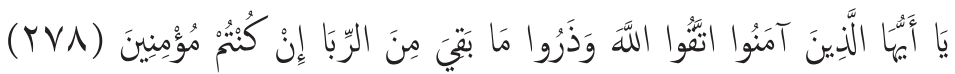
Artinya:

Hai orang-orang yang beriman, bertakwalah kepada Allah dan tinggalkan sisa Riba (yang belum dipungut) jika kamu orangorang yang beriman." (Al-Baqarah: 278).

d. Mempermainkan takaran, timbangan dan kualitas

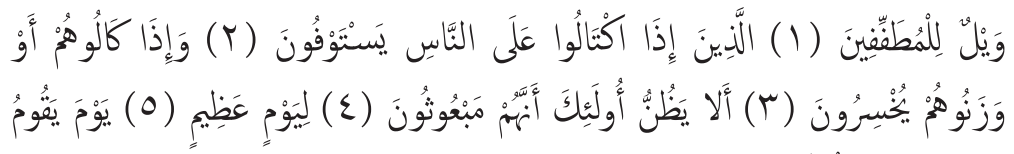

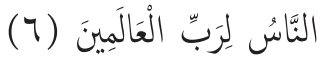

Artinya:

Kecelakaan besarlah bagi orang-orang yang curang (yaitu) orang-orang yang apabila menerima takaran dari orang lain mereka minta dipenuhi, dan apabila mereka menakar atau menimbang untuk orang lain, mereka mengurangi. tidaklah orang-orang itu menyangka, bahwa Sesungguhnya mereka akan dibangkitkan, pada suatu hari yang besar, (yaitu) hari (ketika) manusia berdiri menghadap Tuhan semesta alam?" (Al-Muthaffifin: 1-6)

e. Memfitnah dan cara-cara yang tidak benar lainnya

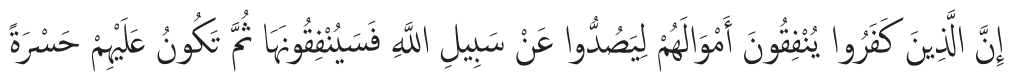




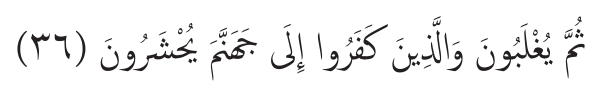

Artinya:

Sesungguhnya orang-orang yang kafir menafkahkan harta mereka untuk menghalangi (orang) dari jalan Allah. mereka akan menafkahkan harta itu, kemudian menjadi sesalan bagi mereka, dan mereka akan dikalahkan. dan ke dalam Jahannamlah orang-orang yang kafir itu dikumpulkan."(AlAnfaal:36)

Sabda Nabi Shalallahu 'alaihi wasallam.,

"Seseorang di hari kiamat nanti pasti tidak terlepas dari empat pertanyaan: usia (umur) dihabiskan untuk apa, masa muda dipergunakan untuk apa, harta benda bagaiamana cara mendapatkan dan memanfaatkannya, dan ilmu pengetahuan diamalkan untuk apa." (HR. Tirmidzi).

\section{Dampak Riba dan Sedekah}

\section{Riba}

\section{a. Secara Personal}

1. Riba adalah perbuatan yang diharamkan Allah Shubahanahu wa ta 'ala karena didalamnya terdapat unsur kezaliman terhadap harta orang lain. (Al-Baqarah: 275\& An-Nisa’: 4).

2. Membuat para pelaku riba menjadi pemalas, hal ini dikarenakan mereka mendapatkan keuntungan yang sangat mudah.

3. Dapat menghilangkan ukhuwah antara sesama kaum muslimin.

4. Dr. Abdul Azis Ismail (Dosen disalah satu fakultas kedokteran di Mesir) dalam bukunya menyatakan bahwa riba merupakan satu penyebab terjadinya berbagai penyakit jantung. Dikarenakan seorang pelaku riba memiliki sifat tamak dan kikir terhadap harta bahkan samapai pada tahap sebagai pemuja harta. Padahal 
roda ekonomi berputar tidak selamanya searah dan teratur. Maka tatkala terjadi gunjang-ganjing ekonomi maka tidak jarang penyakit jantung berjangkit melanda para pelaku riba dengan gejala tekanan darah tinggi, bahakan berakibat stroke, pendarahan di otak dan mati mendadak.

\section{b. Ekonomi}

1. Semakin tinggi suku bunga, semakin tinggi juga harga yang akan ditetapkan pada suatu barang (inflasi).

2. Dampak lainnya adalah utang, dengan rendahnya tingkat penerimaan peminjam dan tingginya biaya bunga, akan menjadikan peminjam tidak pernah keluar dari ketergantungan, terlebih lagi bila bunga atas utang tersebut dibungakan (Erwandi Tarmizi, h. 337).

3. Merusak sumber daya manusia. Ar-razy (Wafat $606 \mathrm{H}$ ) dalam tafsirnya menjelaskan bagaimana peranan riba menciptakan manusia yang malas bekerja dan takut mengambil resiko untuk mengembangkan hartanya. Ia berkata, "Allah telah mengharamkan riba, karena menghalangi manusia untuk giat berusaha. Seorang pemilik dirham bila yakin akan meraih laba dari akad riba dengan cara meminjamkan uang ke pihak lain tanpa harus mengeluarkan keringat dan tanpa menuai kerugian tentu dia tidak akan mau bekerja yang belum tentu akan mendapat laba dan mungkin yang terjadi sebaliknya, ia malah menderita kerugian. Olehnya itu kemaslahatan tidak akan berjalan dengan baik tanpa ada perdagangan, kerja dan pembangunan.

4. Penyebab utama dalam inflasi adalah riba, karena produsen yang mendapatkan modal dari pinjaman berbunga pasti akan menambahkan bunga yang harus dibayarkan kepada debitur kedalam harga barang produksinya. Jadi harga jual barang yang diproduksi sama dengan biaya produksi ditambah bunga. 


\section{c. Sosial Kemasyarakatan}

1. Riba merupakan pendapatan yang didapat secara tidak adil.

2. Para pengambil riba menggunakan uangnya untuk memerintahkan orang lain agar berusaha dan mengembalikan dalam jumlahnya yang lebih besar. Misalnya, dua puluh lima persen lebih tinggi dari jumlah yang dipinjamkannya.

3. Tidak akan menimbulkan msayarakat yang madani. Hal ini dikarenakan seorang anggota masyarakat yang melakukan praktik riba, ia tanpa perikemanusian selalu berusaha menghisap harta setiap anggota masyarakat yang lainnya.

\section{Sedekah}

\section{a. Personal}

1. Suatu bentuk penghambaan seorang insan kepada Allah selaku Pencipta, Pemilik, dan Pengatur alam semesta beserta segala isinya melalui pengorbanan harta. (Al-Baqarah: 277 \& AtTaubah: 60 ).

2. Memberikan semangat dan etos kerja kepada kaum muslimin dikarenakan adanya kewajiban tolong-menolong orang-orang yang miskin.

3. Menumbuhkan ukhuwah antara sesama kaum muslimin.

\section{b. Ekonomi}

1. Media sirkulasi kekayaan agar harta tidak berputar di kalangan orang-orang kaya saja.

2. Zakat adalah instrumen pemerataan pendapatan ekonomi masyarakat pada masyarakat Muslim, agar kesenjangan ekonomi dapat dikurangi melalui penyaluran zakat kepada orang-orang miskin (Didin Hafidhuddin \& Ahmad Juwaini, 2007 : h. 3).

3. Selain fungsi pemerataan, zakat yang dibagikan kepada orang- 
orang miskin juga difungsikan sebagai modal untuk menciptakan usaha baru, menciptakan lapangan kerja baru, dan menjadi nilai tambah bagi masyarakat dalam mengelola sumber daya alam yang ada sehingga bernilai produktif.

4. Adapun tujuan dalam jangka panjang, zakat juga bertujuan untuk mewujudkan suatu masyarakat yang hidup sejahtera dan mandiri tanpa bergantung pada belas kasihan orang lain atau tanpa harus meminta-minta kepada masyarakta lainnya.

\section{c. Sosial Kemasyarakatan}

1. Mengatasi kelaparan dan rasa sakit.

2. Mengatasi kesulitan tempat tinggal

3. Menyediakan atau membantu pendidikan masyarakat.

4. Mengatasi kesulitan pada saat darurat atau mendesak (contohnya memenuhi kebutuhan pokok dan kebutuhan dasar manusia lainnya pada saat terjadi bencana) (Ibid, h. 4).

Dari pemaran diatas menjelaskan mengenai perbandingan dampak riba dan dampak sedekah baik secara personal, ekonomi maupun sosial kemasyarakatan. Dampak riba memberikan pengaruh negatif bagi masyarakat dan negara, hal dikarenakan perbuatan riba dapat merusak ukhuwah dan memberikan ketergantungan utang bagi negara-negara miskin dan negara berkembang. Sebaliknya dampak sedekah memberikan dampak positif bagi masyarakat dan negara, dikarenakan dengan sedekah menumbuhkan rasa ukhuwah dan meningkatkan perekonomian suatu negara.

\section{Penutup}

Dari hasil penulisan diatas dapat disimpulkan bahwa sumber yang menjadi permasalahan utama dalam perkonomian adalah adanya keserakahan manusia. Keinginan yang timbul dan rasa yang tidak pernah puas terhadap segala yang dimilikinya. Ininlah yang menjadi penyebab 
mereka rela melakukan pelanggaran-pelanggaran syariah demi memaksimalkan profit atau keuntungan duniawi saja.

Dalam pandangan syariah riba adalah sesuatu yang diharamkan. Tambahan yang didapatkan dalam riba sesungguhnya tidak bertambah disisi Allah Ta'ala dan kelak diakhirat mereka akan mendapatkan balasan atas pelanggaran syariah yang mereka lakukan. Sebaliknya sedekah adalah salah satu ibadah yang diperintahkan Allah Ta'ala sebagai kewajiban kaum muslimin. Sesungguhnya sedekahlah yang Allah lipatgandakan balasan dan pahalanya.

Disamping itu riba memiliki dampak yang negatif dalam berbagai aspek kehidupan, baik itu aspek personal berupa sifat malas atau etos kerja yang kurang dikarenakan mereka mendapatkan keuntungan yang sangat mudah. Aspek Ekonomi dapat menaikkan harga-harga barang (inflasi) dikarena beban bunga pinjaman yang terus meningkat. Aspek sosial masyarakat dapat menimbulkan kesenjangan antara orang miskin dan orang kaya arena tidak berjalannya distirbusi harta dengan baik.

Sebaliknya sedekah memiliki dampak yang positif dalam berbagai aspek kehidupan, baik itu aspek personal berupa peningkatan nilainilai ukhuwah (persaudaraan) karena didalam terdapat proses ta'awun (kerja sama). Menunjang dalam Aspek ekonomi dapat mendistibusiakan harta kepada orang miskin dan orang kaya sehingga tidak ada lagi gap antara mereka. Dalam aspek sosial dapat membantu kaum muslimin yang membutuhkan bantuan berupa pendidikan, kesehatan, tempat tinggal, maupun bantuan yang mendesak berupa bahan pangan jika terjadi bencana alam. 


\section{Daitar Pustaka}

Ali, Zainuddin, Hukum perbankan Syariah, Jakarta : Sinar Grafika, 2008. Alu Syaikh, Abdullah bin Muhammad, Tafsir Ibnu Katsir Jilid 1, (Penerj. M. 'Abdul Ghoffar E.M \& Abu Ihsan al-Atsar), Jakarta: Pustaka Imam Asy-Syafi'i, Cet. 1, 2008.

, Tafsir Ibnu Katsir Jilid 7, (Penerj. M. 'Abdul Ghoffar E.M \& Abu Ihsan al-Atsar), Jakarta: Pustaka Imam Asy-Syafi'i, Cet. 1, 2008.

Antonio, Muhammad Syafi'i, Bank Syariah; Dari Teori ke Praktek, Cet. 9, Jakarta: Gema Insani, 2005

Az-Zuhaili Wahbah, at-Tafsîr al-Munîr fi al-'Aqîdah wa asy-Syarîah wa al-Manhaj, Damaskus: Dâr al-Fikr, 1998

Bin Badri, Muhammad Arifin, Riba dan Tinjauan Kritis Perbankan Syariah Penjelasan Secara Rinci Mengenai Macam-macam Riba dan Contoh Prakteknya Pada Zaman Ini, Cet. 5, Bogor: Darul Ilmi Publishing, 2012

Chapra , M. Umer, Islam dan Tantangan Ekonomi, Jakarta: Gema Insani Press, 2000

Dawwabah, Muhammad Asyraf Dawwabah, Menjadi Entrepreneur Muslim Tahan Banting, (Penj: Budiman Mustofa), Solo: Ziyad Visi Media: 2009.

Hafidhuddin, Didin, Agar Harta Berkah \& Bertambah, Jakarta: Gema Insani, Cet. 2, 2008.

, Panduan Praktis Tentang Zakat Infak Sedekah, Jakarta: Gema Insani, Cet. IV, 2008.

Hafidhuddin, Didin \& Ahmad Juwaini, Membangun Peradaban Zakat, Ciputat: Divisi Publikasi Institusi Manajemen Zakat, Cet. I, 2007.

Muhammad, Lembaga-lembaga Keuangan Umat kontemporer, Yogyakarta: UII Press, 2000. 
Tarmizi, Erwandi, Harta Haram Muamalat Kontemporer, Bogor: Berkat Mulia Insani, Cet. IV, 2013.

Azizy, Satria Hibatal, Sedekah dan Keutamaanya, www.kaliakbar.com, di akses pada tanggal 05 Juni 2013 pukul. 07.31 WIB. 